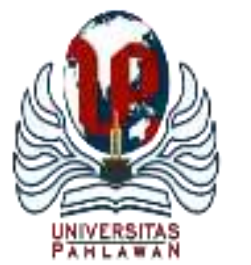

Edukatif : Jurnal Ilmu Pendidikan Volume 3 Nomor 6 Tahun 2021 Halm 3884 - 3897

EDUKATIF: JURNAL ILMU PENDIDIKAN

Research \& Learning in Education

https://edukatif.org/index.php/edukatif/index

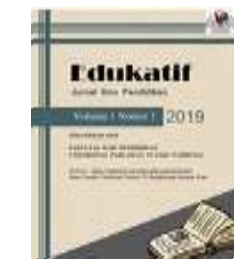

\title{
Perencanaan Strategi Guru dalam Pembelajaran Pendidikan Agama Islam pada masa Covid-19
}

\author{
Wahid Hasim $^{1 凶}$, Kusen $^{2}$, Hartini $^{3}$, Mirzon Daheri ${ }^{4}$ \\ Institut Agama Islam Negeri (IAIN) Curup, Indonesia ${ }^{1,2,3,4}$

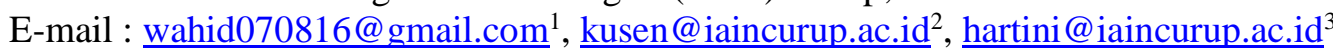 \\ mirzondaheri@iaincurup.ac.id ${ }^{4}$
}

\begin{abstract}
Abstrak
Adanya COVID-19 yang menyebar keseluruh dunia, termasuk di Indonesia telah menimbulkan banyak korban jiwa. Hal ini memaksa pemerintah mengeluarkan kebijakan Pembelajaran Jarak Jauh, diantaranya melalui daring, agar kegiatan pendidikan tetap berjalan, termasuk Pendidikan Agama Islam. Tentunya guru memerlukan perencanaan strategi yang berbeda dari perencanaan strategi sebelumnya, dalam menanamkan nilai-nilai Islam kepada siswa yang menjadi bagian penting tujuan pendidikan nasional. Tujuan penelitian ini untuk mengetahui dan memahami bagaimana perencanaan strategi guru dalam pembelajaran Pendidikan Agama Islam akibat COVID-19. Teknik pengumpulan datanya melalui wawancara terhadap 5 orang responden sebagai informan. Hasil yang didapat yaitu bahwa guru menempuh perencanan strategi pembelajaran dengan membangun kesiapan siswa dalam pembelajaran, mendesain perencanaan pembelajaran, penggunaan strategi dan metode, penggunaan media, sumber belajar dan bahan ajar, alokasi waktu, dan penilaian hasil belajar formatif.
\end{abstract}

Kata Kunci: Perencanaan, Strategi Guru, Pendidikan Agama Islam, COVID-19.

\begin{abstract}
COVID-19 is spreading all over the world, including in Indonesia has caused many casualties. This forces the government to secrete policy or strategy distance education, including through the network, to keep it running, including Islamic Education. Teachers naturally need planning of strategies that are different from those previously, in embed Islamic values to a student, which becomes an urgent aim national education. This aim research for knowledge and understand how the planning of strategies teacher in Islamic education consequence COVID-19. Technique collection the data through interview to five people respondent as an informant. The results obtained are that teachers take learning strategy planning by building student readiness in learning, designing lesson plans, using strategies and methods, using media, learning resources and teaching materials, time allocation, and assessing formative learning outcomes.
\end{abstract}

Keywords: Teacher Strategy, Planning, Islamic Religious Education, COVID-19.

Copyright (c) 2021 Wahid Hasim, Kusen, Hartini, Mirzon Daheri

$\triangle$ Corresponding author

Email : wahid070816@gmail.com

DOI : https://doi.org/10.31004/edukatif.v3i6.1147

ISSN 2656-8063 (Media Cetak)

ISSN 2656-8071 (Media Online)

Edukatif : Jurnal Ilmu Pendidikan Vol 3 No 6 Tahun 2021 p-ISSN 2656-8063 e-ISSN 2656-8071 
3885 Perencanaan Strategi Guru dalam Pembelajaran Pendidikan Agama Islam pada masa Covid-19- Wahid Hasim, Kusen, Hartini, Mirzon Daheri

DOI: https://doi.org/10.31004/edukatif.v3i6.1147

\section{PENDAHULUAN}

Adanya Covid-19 yang berasal dari Wuhan-Tiongkok kemudian menyebar keseluruh negara di dunia, termasuk di Indonesia telah menimbulkan banyak korban jiwa. Menurut data WHO kamis (8/7/2021) jumlah korban meninggal akibat COVID-19 di seluruh dunia mencapai 3.992.680 orang dari 184.324.026 kasus, di Indonesia berada pada posisi ke 17 di dunia, dengan korban wafat mencapai 62.908 orang (Ayp, 2021). Hal tersebut telah meruntuhkan sendi-sendi kehidupan di semua bidang, termasuk bidang pendidikan, sehingga memaksa pemerintah mengeluarkan PP Nomor 21 tahun 2020 tentang Pembatasan Sosial Bersekala Besar (PSBB) dalam rangkan percepatan penanganan COVID-19 di seluruh wilayah Republik Indonesia (Mensesneg). Kemudian dilanjutkan dengan Instruksi Mendagri Nomor 15 tahun 2021 tentang Pemberlakuan Pembatasan Kegiatan Masyarakat (PPKM) Darurat Corona Virus Disease 2019 di wilayah Jawa dan Bali, dan Instruksi Mendagri Nomor 22 tahun 2021 tentang Pemberlakuan Pembatasan Kegiatan Masyarakat Level 4 Corona Virus Disease 2019 di Wilayah Jawa dan Bali (Instruksi Menteri Dalam Negeri Nomor 22 Tahun 2021 - Regulasi | Covid19.go.id, 2021) yang dianggap zona merah dan oranye penularan COVID-19 Varian baru (Alfa B.1.1.7 dari Ingris, Beta B.1 dari Afrika Selatan, Gama P1 dari Brazil, dan Delta B 1.6172 dari India). Penerapannya melalui pembatasan pergerakan masyarakat atau isolasi mandiri dalam arti tidak keluar rumah atau membatasi keluar rumah selama pemerintah mengeluarkan kebijakan dimaksud, tujuannya untuk menghindari dan memutus mata rantai penularan COVID-19, sehingga jumlah penderita dan korban meninggal dapat diminimalisir dan atau ditiadakan. Artinya kegiatan pekerjaan disejumlah bidang tertentu dilakukan dari rumah. PSBB dan PPKM darurat tersebut tersebut meliputi peliburan sekolah dan tempat kerja; pembatasan kegiatan keagamaan, pembatasan kegiatan di tempat atau fasilitas umum, pembatasan kegiatan sosial dan budaya, pembatasan moda transportasi dan pembatasan kegiatan lainnya, khusus terkait aspek pertahanan dan keamanan tidak termasuk didalamnya (Pedoman Pembatasan Sosial Berskala Besar dalam Rangka Percepatan Penanganan Corona Virus Disease (COVID-19), 2020).

Begitu juga di bidang pendidikan tidak luput dari dampak COVID-19 ini, sehingga Menteri Pendidikan dan Kebudayaan RI Nadiem Anwar Makarim mengeluarkan Surat Edaran No. 4 tanggal 19 Maret 2020 tentang pelaksanaan penddidikan dalam masa darurat penyebaran COVID-19, dalam isi surat pada nomor 2 yang intinya menyatakan bahwa proses kegiatan belajar mengajar dilakukan dari rumah melalui pembelajaran daring/jarak jauh, tujuannya untuk kesehatan lahir lahir dan batin siswa, guru, kepala sekolah, dan seluruh warga sekolah (Surat Edaran Nomor 4 Tahun 2020 tentang Pelaksanaan Kebijakan Pendidikan dalam Masa Darurat Penyebaran Corona Virus Disease (COVID-19), 2020). Dengan kebijakan tersebut, Muhammad Pelaksana Tugas Direktur Jenderal Pendidikan Anak Usia Dini, Dasar dan Menengah menyatakan bahwa proses pembelajaran di semua jenjang pendidikan dilaksanakan dari rumah dengan Pembelajaran Jarak Jauh melalui dalam jaringan (online) dan luar jaringan (off line) (Prodjo, 2020).

Dengan diberlakukannya PJJ, berimplikasi (mempunyai hubungan keterlibatan langsung) terhadap perencanaan strategi guru dalam melakukan kegiatan pembelajaran, yang tentunya memerlukan perencanaan strategi berbeda dari perencanaan strategi pembelajaran tatap muka. Untuk itulah penelitian ini dilakukan dalam rangka menilik bagaimana perencanaan strategi guru dalam pembelajaran Pendidikan Agama Islam melalui PJJ Daring. Penelitian ini bertujuan untuk mengetahui dan mendeskrifsikan perencanaan strategi guru dalam pembelajaran Pendidikan Agama Islam melalui PJJ Daring.

Dalam pasal 1 undang-undang no. 14 tahun 2005 tentang guru dan dosen dinyatakan bahwa guru adalah pendidik profesional dengan tugas utama mendidik, mengajar, membimbing, mengarahkan, melatih, menilai, dan mengevaluasi peserta didik pada anak usia dini jalur pendidikan formal, pendidikan dasar dan pendidikan menengah (Mensesneg: 2015). Guru sebagai pendidik tentunya memerlukan strategi dalam proses pembelajaran yang meliputi tiga aspek yaitu perencanaan strategi, pelaksanaan strategi, dan evaluasi strategi. Dalam penelitian ini yang akan dibahas perencanaan strategi. Dalam KBI (2008) perencanaan berasal dari 
kata rencana artinya rangka sesuatu yang akan dikerjakan. Menurut Sanjaya rencana adalah pengambilan keputusan tentang apa yang harus dikerjakan untuk mencapai tujuan, dalam prosesnya diawali dari langkahlangkah yang harus dilakukan untuk mencapai tujuan tersebut (Sanjaya, 2008, hal. 54). Selanjutnya menurut Kamus Besar Bahasa Indonesia, strategi adalah rencana yang cermat mengenai kegiatan untuk mencapai sasaran khusus (Kementerian Pendidikan dan Kebudayaan RI, n.d.). Ahmadi dan prasetya mendefinisikan strategi adalah suatu garis besar haluan dalam bertindak untuk mencapai sasaran yang telah ditentukan, jika dihubungkan dengan kegiatan belajar mengajar, strategi diartikan sebagai pola umum kegiatan guru murid dalam perwujudan kegiatan belajar mengajar untuk mencapai tujuan yang telah digariskan (Ahmadi \& Prasetya, 2005). Pengertian perencanaan strategi tersebut bila dihubungkan dengan konteks guru dalam pembelajaran, menurut Majid suatu proses penyusunan materi pelajaran, penggunaan media pengajaran, penggunaan pendekatan, metode pengajaran, dan penilaian dalam suatu alokasi waktu yang akan dilaksanakan pada masa tertentu untuk mencapai tujuan yang telah ditentukan (Majid, 2014, hal. 146). Perencanaan strategi guru dalam pembelajaran meliputi silabus dan RPP yang komponennya terdiri dari identitas pebelajaran, standar kompetensi, kompetensi dasar, indikator pencapaian kompetensi, tujuan pembelajaran, materi ajar, alokasi waktu, metode pembelajaran, kegiatan pembelajaran, penilaian hasil belajar, dan sumber belajar (Sudirman, 2020).

Pembelajaran Pendidikan Agama Islam merupakan salah satu komponen mata pelajaran yang harus dilaksanakan guru untuk menanamkan nilai-nilai agama kepada siswa supaya menjadi manusia yang beriman dan bertaqwa sebagaimana tujuan pendidikan nasional. Tujuan Pendidikan Agama Islam adalah pembentukan perubahan sikap dan tingkah laku sesuai dengan petunjuk ajaran agama Islam (Sugiana, 2019). Sebagaimana yang telah dilakukan Nabi Muhammad SAW dalam usaha menyampaikan seruan ajaran agama dengan berdakwah, menyampaikan ajaran, memberi contoh, melatih keterampilan berbuat, memberi motivasi dan menciptakan lingkungan sosial yang mendukung pelaksanaan ide pembentukan pribadi muslim. Untuk itu perlu adanya usaha, kegiatan, cara, alat, dan lingkungan hidup yang menunjang keberhasilannya. Muntholi'ah (2002) mendefinisikan Pendidikan Agama Islam adalah usaha yang lebih khusus ditekankan untuk mengembangkan fitrah keberagamaan subyek peserta didik agar lebih mampu memahami, menghayati, dan mengamalkan ajaran-ajaran Islam (Rafsanjani \& Razaq, 2019). Selain itu Pendidikan Agama Islam bukanlah sekedar proses usaha mentransfer ilmu pengetahuan atau norma agama, melainkan juga berusaha mewujudkan perwujudan jasmani dan rohani dalam peserta didik agar kelak menjadi generasi yang memiliki watak, budi pekerti, dan kepribadian yang luhur kepribadian muslim yang utuh.

Dari hasil kajian para peneliti terdahulu menyatakan bahwa Pendidikan Agama Islam dapat dilakukan dengan PJJ belajar dari rumah (BDR) Daring, meskipun pada kenyataannya ditemukan sejumlah masalah dalam pelaksanaannya. Sebenarnya, PJJ BDR tetap dapat dilaksanakan dengan kerjasama yang baik dari guru, siswa dan orang tua (Warianie, 2020). Walaupun ada sejumlah kendala: sarana dan prasarana, penguasaan teknologi, biaya, komunikasi, dan bantuan pemerintah diperlukan. Sa'dullah menyatakan bahwa PJJ dalam pembelajaran PAI terlaksana dengan baik, efektif dan efisien, siswa menjadi kreatif, cerdas, dan mandiri, meskipun ada kendala biaya, jaringan internet, kurangnya minat siswa, pemahaman terhadap IT, dan guru lebih banyak menghabiskan waktu (Sa'dullah, 2020). Kemudian Zulfikar menerangkan bahwa kesiapan orang tua diperlukan dalam BDR yakni sabar, percaya diri, dan tenang dalam membimbing anak. Kendalanya anak mudah marah, menangis, dan melawan akibat tugas terlalu banyak dan bingung untuk bertanya sehingga semangat belajar menurun (Zulfikar, 2020). Sarannya guru dalam mengajar membuat video dan atau pembelajaran menggunakan aplikasi Zoom. Selain itu juga menggunakan Google Classroom, Google Forms, Whatsapp, Facebook, dan Metode Discovery Learning. Sehingga, dari penelitian-penelitian terdahulu terlihat belum ada kajian khusus terkait dengan perencaan yang dilakukan oleh guru dalam prosespembelajaran daring saat ini.

Tujuan dilakukannya penelitian ini untuk mengetahui bagaimana perencanaan strategi guru melalui PJJ 
3887 Perencanaan Strategi Guru dalam Pembelajaran Pendidikan Agama Islam pada masa Covid-19- Wahid Hasim, Kusen, Hartini, Mirzon Daheri

DOI: https://doi.org/10.31004/edukatif.v3i6.1147

Daring dalam pembelajaran Pendidikan Agama Islam akibat COVID-19. Hasil yang diharapkan adalah mengetahui dan memahami bagaimana sebenarnya perencanaan strategi guru yang diterapkan saat PJJ Daring dalam Pembelajaran Pendidikan Agama Islam sebagai kebijakan pemerintah akibat COVID-19 yang sedang mewabah.

\section{METODE PENELITIAN}

Penelitian ini menggunakan metode kualitatif. Penelitian kualitatif adalah penelitian yang menghasilkan data deskriftif berupa kata-kata tertulis atau lisan dan perilaku dari orang-orang yang diamati (Rahman \& Hidayat, 2019). Pendekatan yang digunakan diskriptif kualitatif yaitu menggambarkan suatu keadaan atau fenomena kejadian yang diteliti apa adanya serta diarahkan untuk memaparkan fakta-fakta, kejadian-kejadian secara sistematis dan akurat (Arikunto, 2010, hal. 53). Dalam hal ini penelitian memaparkan tentang perencanaan strategi guru dalam pembelajaran Pendidikan Agama Islam melalui PJJ Daring di SMPIT AnNida' Lubuklinggau, penelitian dilakukan dari bulan maret sampai bulan juli 2021. kemudian dieksplorasi dengan teori-teori yang ada, selanjutnya dianalisis dan diambil kesimpulan. Subjek penelitian sebagai informan berjumlah 5 orang yaitu kepala sekolah (X1), wakil kepala sekolah bidang kurikulum (X2), dan 3 orang guru Pendidikan Agama Islam (X3, X4, X5). Teknik pengumpulan data yang digunakan yaitu wawancara. Menurut Riyanto (2001) wawancara atau interview merupakan metode pengumpulan data yang menghendaki komunikasi langsung antara peneliti dengan subjek atau responden. Data yang didapat dianalisis dengan menggunakan tematik, yaitu teknik analisa data yang menekankan pada penyusunan koding dengan mengacu pada pertanyaan penelitian yang telah ditetapkan, sehingga tema-tema yang tersusun sesuai dengan pertanyaan penelitian dan menjadi acuan dalam memaparkan fenomena yang terjadi (Heriyanto, 2019). Instrumen wawancara dapat dilihat pada tabel 1 berikut ini:

\begin{tabular}{|c|c|c|c|}
\hline $\begin{array}{c}\text { Fokus } \\
\text { Penelitian }\end{array}$ & Indikator & Pertanyaan Penelitian & Informan \\
\hline $\begin{array}{c}\text { Pembelajaran } \\
\text { Jarak Jauh } \\
\text { Dalam } \\
\text { Jaringan }\end{array}$ & $\begin{array}{c}\text { Perencanaan } \\
\text { Strategi Guru } \\
\text { dalam } \\
\text { pembelajaran } \\
\text { Pendidikan } \\
\text { Agama Islam }\end{array}$ & $\begin{array}{l}\text { 1. Bagaimana kesiapan siswa ? } \\
\text { 2. Bagaimana perencanaan pembelajaran? } \\
\text { 3. Strategi apa yang digunakan ? } \\
\text { 4. Media apa yang digunakan? } \\
\text { 5. Metode apa yang digunakan? } \\
\text { 6. Bahan ajar dan sumber belajar apa yang } \\
\text { digunakan? } \\
\text { 7. Berapa lama alokasi waktu yang digunakan? } \\
\text { 8. Bagaimana penilaian hasil belajar setelah } \\
\text { kegiatan pembelajaran? }\end{array}$ & $\begin{array}{l}X 1, X 2 \\
X 2, X 3, X 4, X 5 \\
X 1, X 2, X 3 \\
X 3, X 4, X 5 \\
X 3, X 4, X 5 \\
X 3, X 4, X 5 \\
X 1, X 3, X 4, X 5 \\
\text { X3, X4, X5 }\end{array}$ \\
\hline
\end{tabular}

Paparan alur penelitian ini secara lebih rinci dapat dilihat pada gambar 1 berikut ini :

\section{Fokus penelitian \\ Perencanaan \\ Strategi Guru}
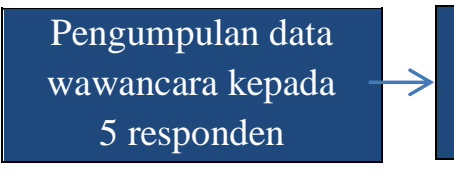

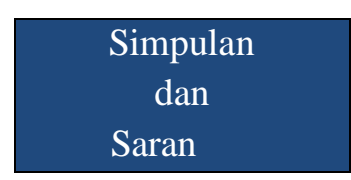

\section{HASIL PENELITIAN DAN PEMBAHASAN}

Pembelajaran merupakan suatu kombinasi yang tersusun meliputi unsur manusia, fasilitas, perlengkapan, dan prosedur yang saling mempengaruhi tercapainya tujuan pembelajaran. Undang-Undang Sisdiknas 2003 Pasal 1 menjelaskan bahwa pendidikan adalah usaha sadar dan terencana untuk mewujudkan Susana belajar dan proses pembelajaran agar peserta didik secara aktif mengembangkan potensi dirinya untuk 
memiliki kekuatan spiritual keagamaan, pengendalian diri, kepribadian, kecerdasan, akhlak mulia, serta keterampilan yang diperlukan dirinya, masyarakat, bangsa, dan negara. Untuk mewujudkannya, guru tentu memerlukan perencanaan strategi yang tepat dalam proses belajar mengajar. Secara lebih rinci, perencanaan strategi guru selama diberlakukannya PJJ BDR Daring akan dipaparkan sebagai berikut:

\section{Kesiapan Siswa dalam Pembelajaran}

Kesiapan siswa dalam PJJ BDR Daring mutlak diperlukan, tanpa adanya kesiapan proses belajar mengajar yang menjadi tujuan pembelajaran tidak akan tercapai. Salah satu tujuan pembelajaran Pendidikan Agama Islam pada tujuan operasional, adalah merupakan tujuan praktis yang akan dicapai dengan sejumlah kegiatan tertentu yang dilaksanakan pada setiap unit kegiatan pembelajaran dan mempunyai tujuan tertentu yang dicapai, misalnya siswa terampil melakukan, lancar mengucapkan, mengerti, memahami, meyakini, dan menghayati materi yang diajarkan seperti bisa tata cara shalat, membaca al-Qur'an, tingkah lakunya baik dan lain-lain (Khamim, 2019).

Untuk kesiapkan siswa melalui PJJ BDR Daring diawali dengan mengadakan rapat dengan dewan guru, tenaga kependidikan, dan orang tua siswa, tujuannya untuk menyiapkan sarana dan prasarana, biaya, menganjurkan kepada orang tua siswa untuk selalu menjaga kesehatan dengan menerapkan protokol COVID19, mendampingi anaknya ketika belajar daring (kutipan wawancara X1).

Kesiapan siswa adalah kemampuan yang cukup, baik fisik, mental, dan perlengkapan belajar (Ma'shumah \& Muhsin, 2019). Kesiapan fisik berarti tenaga yang cukup dan kesehatan yang baik, kesiapan mental berarti memiliki minat dan motivasi yang cukup untuk melakukan suatu kegiatan, dan perlengkapan belajar adalah alat-alat yang digunakan. Kesiapan juga dapat dipahaimi sebagai keseluruhan kondisi individu yang dapat memberikan respon atau jawaban dengan cara tertentu terhadap situasi tertentu, kesiapan merupakan suatu keadaan siap untuk memberikan respon atau jawaban akan sesuatu dengan cara tertentu untuk menjawab atau merespon tergantung dengan apa yang sedang dihadapi (Reski \& A Ilyas -, 2019).

Kesiapan setiap siswa amatlah penting untuk merespon atau menjawab keadaan dimana proses belajar mengajar dilakukan melalui PJJ BDR Daring. Kesiapan tersebut meliputi kesiapan fisik, dimana siswa memiliki tenaga yang cukup dan kesehatan yang baik, artinya siswa harus selalu menjaga kesehatan dengan menerapkan SOP protokol COVID-19 yakni 5M yaitu Memakai masker, Mencuci tangan, Menjaga jarak, Menghindari kerumunan, dan Mengurangi mobilitas (Novitasarii, 2021). Begitu juga kesiapan mental amatlah dibutuhkan, dimana siswa dituntut untuk memiliki minat dan motivasi yang tinggi dalam melakukan kegiatan pembelajaran oleh karenanya dibutuhkan peran orang tua. Peran orang tua sangat dibutuhkan dalam pelaksanaan PJJ, salah satunya selalu mendampingi anaknya ketika pembelajaran daring berlangsung (Parlindungan et al., 2020). Kemudian mempersiapkan sarana dan prasarana pembelajaran daring sama pentingnya seperti laptop, komputer, handphone android atau smartphone, internet, kuota, dan biayanya.

\section{Perencanaan Pembelajaran}

Perencanaan merupakan rangka sesuatu yang akan dikerjakan. Salah satu perencanaan guru dalam pembelajaran yakni menyiapkan rencana pelaksanaan pembelajaran (RPP)yang merupakan pedoman untuk kegiatan belajar mengajar, agar pelaksanaan pembelajaran berjalan dengan baik dan mendapatkan tujuan pembelajaran sesuai keinginan (Vidiarti et al., 2019).

Di SMPIT An-Nida' Lubuk Linggau setiap guru yang mengajar diwajibkan membuat Rencana Pelaksanaan Pembelajaran Daring dan dibuat satu lembar setiap satu kali pertemuan untuk setiap pokok bahasan materi pelajaran yang akan diajarkan kepada siswa. Ini dilakukan guru sesuai dengan surat edaran menteri pendidikan dan kebudayaan nomor 14 tahun 2019 tentang Penyederhanaan Rencana Pelaksanaan Pembelajaran. (kutipan wawancara X2). Perencanaan pembelajaran PAI diawali dari pembuatan RPPD yang berpedoman pada kurikulum 2013, dan dibuat sesederhana mungkin yaitu satu pokok bahasan untuk satu kali 
pertemuan dibuat satu lembar, dibuatnya atas inisiatif sendiri karena tidak ada pedoman untuk membuat RPPD dari kemendikbud (kutipan wawancara X3).

Guru mengakui hal ini, sebelum melakukan kegiatan belajar mengajar guru menyiapkan RPPD. Dalam membuatnya yang terpenting untuk pencapaian kurikulum dimasa pandemi COVID-19 ini, menyampaikan materi pelajaran kepada siswa makna-makna yang terkandung dalam kompetensi dasar setiap pokok bahasan dalam belajar (kutipan wawancara (X4). Dalam pembuatan RPPD yang penting ditekankan pada maknamakna yang terkandung dalam Kompetensi Dasar Kurikulum 2013. RPPD ini dibuat dengan prinsip efektif, efisien, dan berorientasi pada siswa (kutipan wawancara X5).

Dari kutipan wawancara di atas, guru sebelum melakukan kegiatan belajar mengajar proses perencanaannya diawali dari membuat Rencana Pelaksanaan Pembelajaran Daring yang disingkat RPPD. RPPD ini dibuat satu lembar untuk setiap pokok bahasan materi pelajaran dan disampaikan kepada siswa secara daring untuk satu kali pertemuan. Hal tersebut mereka lakukan berdasarkan surat edaran Mendikbud RI nomor 14 tanggal 10 Desember 2019 yang menyatakan bahwa Pertama, penyusunan RPP dilakukan dengan prinsip efisien, efektif, dan berorientasi pada murid. Kedua, dari 13 komponen RPP yang telah diatur dalam peraturan Menteri Pendidikan dan Kebudayaan Nomor 22 tahun 2016 tentang Standar Proses Pendidikan Dasar dan Menengah, yang menjadi komponen inti adalah tujuan pembelajaran, langkah-langkah (kegiatan) pembelajaran, dan penilaian pembelajaran (assessment) yang wajib dilaksanakan oleh guru, sedangkan komponen lainnya bersifat pelengkap. Ketiga, sekolah, kelompok guru mata pelajaran sejenis dalam sekolah, Kelompok Kerja Guru/Musyawarah Guru Mata Pelajaran (KKG/MGMP), dan individu guru secara bebas dapat memilih, membuat, menggunakan, dan mengembangkan format RPP secara mandiri untuk sebesarbesarnya keberhasilan belajar murid. Keempat, adapun RPP yang telah dibuat tetap dapat digunakan dan dapat pula disesuaikan dengan ketentuan sebagaimana dimaksud pada angka pertama, kedua, dan ketiga.

Pada prinsipya pembuatan RPPD dalam PJJ Daring dimasa pandemi COVID-19 ini yakni efektif, efisien, dan berorientasi pada siswa yang meliputi tiga komponen dasar, pertama menetapkan tujuan pembelajaran untuk tercapainya pendidikan, kedua langkah-langkah pembelajaran yang merupakan kegiatan yang harus dilaksanakan dalam pembelajaran, dan ketiga assesment atau penilaian terhadap siswa dari hasil belajar untuk mengetahui tercapainya tujuan pendidikan. Oleh karenanya guru diberikan kebebasan untuk berinovasi dan berkreasi dalam pembuatan RPPD dimasa pandemi COVID-19 ini, dimana PJJ BDR Daring yang diterapkan saat ini jam belajarnya terbatas.

\section{Penggunaan Strategi dalam Pembelajaran}

Sebelum melakukan kegiatan belajar mengajar, guru seyogyanya memiliki strategi atau penggunaan pendekatan pembelajaran yang baik. Seorang guru pengajar yang professional tidak hanya berfikir tentang apa yang akan dikerjakan, tetapi juga tentang siapa menerima pelajaran, apa makna belajar bagi peserta didik, dan kemampuan apa yang ada pada peserta didik dalam mengikuti pembelajaran (Sulfemi, 2019). Ada beberapa jenis strategi pembelajaran yang dapat diterapkan guru yaitu strategi pembelajaran ekspositori, inquiri, berbasis masalah, koorporatif, contextual teaching and learning (CTL) (Tanzimah, 2020).

Beberapa strategi pembelajaran yang dapat ditempuh guru adalah dengan memberi tugas hafalan ayatayat al-Qur'an dan Hadits, siswa merekam hafalannya dalam bentuk video lalu dikirim ke guru melalui WhatsApp, yang salah diperbaiki, kemudian diadakan pengkajian tentang isi dan kandungan ayat-ayat tersebut, misalnya surat al-kafiaruun (kutipan wawancara X3). Selain menghafal dan mengkaji ayat-ayat alQur'an dan Hadits diadakan tanya jawab, siswa dibawa dibawa kepada masalah-masalah yang nyata dan aktual dalam kehidupan untuk memberikan latihan dan kemampuan dalam menyelesaikan masalah, misalnya kenakalan remaja dan penyalah gunaan narkoba kemudian memberikan tugas, tagihan tugas (kutipan wawancara X4). Dalam kegiatan belajar mengajar terhadap siswa melalui melalui PJJ Daring dilakukan dengan menerangkan materi pelajaran dengan membuat video, power point, voice note, kemudian siswa 
3890 Perencanaan Strategi Guru dalam Pembelajaran Pendidikan Agama Islam pada masa Covid-19- Wahid Hasim, Kusen, Hartini, Mirzon Daheri

DOI: https://doi.org/10.31004/edukatif.v3i6.1147

berinteraksi langsung walaupun melalui WhatsApp, siswa dilibatkan secara penuh untuk mengaitkan materi pelajaran dengan situasi yang ada dan menumbuhkan kesadaran siswa untuk belajar dengan cara mengingatkan, memberikan semangat, dorongan, dan ajakan. Apalagi dimasa COVID-19 ini semangat siswa untuk belajar menurun (kutipan wawancara X5).

Penggunaan strategi dalam pembelajaran memiliki tujuan tertentu yang ingin dicapai terhadap apa yang dilakukan guru. Strategi mengajar merupakan tindakan nyata dari guru atau merupakan praktek guru melaksanakan pengajaran melalui cara tertentu yang dinilai lebih efektif dan efisien (A. Hidayat et al., 2020). Dari hasil penelitian didapatkan bahwa strategi yang digunakan guru dalam pembelajaran yaitu pertama; Strategi afektif. Strategi afektif penekanannya pada kesadaran siswa untuk belajar, dimana guru bisa menumbuhkan kesadaran siswa untuk belajar secara mandiri (Cahyono, 2019). Dalam hal ini guru menumbuhkan kesadaran siswa bisa belajar menghafal ayat-ayat al-Qur' an dan Hadits, hal ini tidaklah mudah dilakukan siswa dalam PJJ Daring kalau tidak tumbuhnya kesadaran dalam melakukannya. Kedua; Strategi inquiri adalah strategi pembelajaran yang penekanannya pada pembangunan intelektual anak, dimana antara guru dengan siswa mengadakan tanya jawab sehingga penekanannya pada proses berfikir siswa secara kritis dan analisis untuk mencari dan menemukan kebenaran. Penggunaan strategi inquiri oleh guru dalam pembelajaran merupakan salah satu cara untuk membangun dan menumbuh kembangkan intelektual siswa, dimana siswa dapat berfikir kritis dan analisis terhadap permasalahan yag dihadapinya (Nursyifah, 2019). Ketiga; Strategi ekspositori. Strategi ekspositori adalah strategi pembelajaran yang menekankan pada proses penyampaian materi secara verbal dari guru kepada siswa dengan maksud agar siswa dapat menguasai materi pelajaran secara optimal (Samsudin, 2021). Penggunaan strategi ini dimana guru menyajikan materi dalam bentuk power point dan guru lebih berperan aktif dalam pembelajaran sedangkan siswa mendengarkan, menyimak, dan mencernanya. Keempat; Strategi pembelajaran berbasis masalah (SPBM) adalah strategi pembelajaran yang dapat membawa siswa kepada pembentukan kemampuan berfikir tingkat tinggi, dimana siswa disuguhkan berbagai situasi permasalahan yang autentik dan bermakna kepada siswa (Fathurrohman, 2020). Strategi ini digunakan guru agar siswa mampu menyikapi dan menyelesaikan masalah-masalah yang terjadi dalam kehidupan mereka, tujuannya untuk memberikan latihan dan kemampuan dalam menyikapi dan menyelesaikan persoalan-persoalan dalam berinteraksi dengan sesame dan lingkungan masyarakat seputarnya. Kelima; Strategi koorporatif adalah strategi pembelajaran yang berfokus pada siswa (student centered) karena adanya interaksi langsung sesama siswa, guru berperan mengarahkan siswa untuk saling berinteraksi dan berbagi informasi tentang pembelajaran dan semua siswa dianggap sama (Megawati et al., 2021). Strategi ini dipakai guru dalam PJJ BDR Daring tentunya berbeda dengan strategi koorporatif pembelajaran tatap muka dimana siswa dapat berinteraksi langsung dengan sesamanya, dalam hal ini siswa berinteraksi langsung untuk berbagi informasi tentang materi pelajaran melalui WhatsApp, Zoom, video, voice note dan lain-lain. Keenam; Strategi Contextual Teaching and Learning (CTL) adalah strategi pembelajaran yang menekankan pada keterlibatan siswa secara penuh dalam proses pembelajaran untuk dapat menemukan situasi kehidupan nyata sehingga mendorong siswa untuk dapat menerapkannya dalam kehidupan (Fahmi et al., 2019; Hasnidar et al., n.d.). Strategi ini digunakan guru dengan cara mendorong siswa untuk menghubungkan antara teori yang dipelajari dengan menerapkannya dalam kehidupan mereka. Strategi ini dapat membantu guru dalam menghubungkan antara konsep materi yang dipelajari siswa dengan kehidupan nyata, misalnya bagaimana akhlak terhadap Allah SWT ? dengan melaksanakan semua perintah-Nya dan menjauhi semua larangan-Nya.

\section{Penggunaan Media Pembelajaran}

Media dalam pelaksanaan kegiatan PJJ BDR Daring sangatlah penting sebagai alat penyampai atau pengantar konten-konten pelajaran guru kepada siswa, tanpa adanya media proses pembelajaran tidak dapat dilaksanakan. Menurut Association of Education and Communication Technology, media adalah alat yang menyampaikan atau mengantarkan pesan-pesan pengajaran (Akbar, 2019; Aripin et al., 2020). 
3891 Perencanaan Strategi Guru dalam Pembelajaran Pendidikan Agama Islam pada masa Covid-19- Wahid Hasim, Kusen, Hartini, Mirzon Daheri

DOI: https://doi.org/10.31004/edukatif.v3i6.1147

Dalam kegiatan belajar mengajar aplikasi yang saya gunakan yaitu WhatsApp Group, Google Forms, dan Zoom. WhatsApp saya gunakan untuk kegiatan belajar mengajar, zoom digunakan untuk pembelajaran tatap muka, dan Google Forms saya gunakan untuk ulangan dan membahas soal-soal (kutipan wawancara $\mathrm{X} 3$ ). Untuk kegiatan pembelajaran saya menggunakan WhatsApp dengan membuat grup WhatsApp dalam setiap kelas yang saya ajar, kemudian Zoom saya gunakan untuk pembelajaran tatap muka dengan siswa, dan Google Forms saya gunakan untuk latihan membahas soal-soal, untuk ulangan penilaian tengah semester, semester, dan ujian sekolah dan ujian nasional (kutipan wawancara X4). Saya menggunakan WhatsApp group sebagai pintu gerbang dalam belajar mengajar, Google Form saya gunakan untuk latihan dan pembahasan soal-soal, untuk ulangan, baik ulangan tengah semester, ulangan semester, maupun ujian sekolah dan ujian nasional, Zoom saya gunakan untuk pembelajaran tatap muka. (kutipan wawancara X2). Penggunaan aplikasi WhatsApp, Google Formulir, dan Zoom ini merupakan kesepakatan antara pihak sekolah dengan dengan orang tua siswa, yang dianggap mudah dalam menggunakannya dan untuk keseragaman (kutipan wawancara $\mathrm{X} 1)$.

Dari hasil penelitian didapatkan bahwa media yang digunakan dalam PJJ BDR Daring yaitu Pertama Whatsapp Group. WhatsApp Group belakangan ini banyak digunakan para pendidik dan pelajar sebagai media komunikasi yang terhalang oleh jarak (Daheri et al., 2020), yang disebut Whats App Group saat ini dijadikan wadah diskusi untuk memecahkan berbagai masalah, pertanyaan, dan sesuatu yang penting yang harus disampaikan terhadap orang-orang yang tergabung didalamnya. Diskusi melalui Whatsapp Group ini sangat membantu penggunanya untuk berkomunikasi dalam Pembelajaran Jarak Jauh. Platform WhatsApp Group saat ini banyak digunakan oleh lembaga pendidikan termasuk di SMPIT An-Nida' Lubuklinggau, dimana platform ini digunakan sebagai aplikasi utama dalam belajar mengajar guru dan siswa dengan membuat WhatsApp group dalam setiap kelas, kedua Google Form. Google Form merupakan salah satu aplikasi berupa template formulir (lembar kerja) yang dapat dimanfaatkan secara mandiri ataupun kolektif untuk tujuan mendapatkan informasi pengguna. Perkembangan teknologi iformasi dan komunikasi menuntut perubahan dalam proses belajar engajar, termasuk dalam pemberian tugas (penugasan) kemahasiswa/siswa. Pada umumnya, pemberian tugas dilakukan dengan menggunakan kedia (kertas), namun dengan adanya Google Forms pemberian tugas dapat dilakukan secara online. Google forms oleh guru digunakan untuk memberikan tugas-tugas kepada siswa seperti mengerjakan soal-soal latihan, untuk ulangan harian, tengah semester, semester, dan ujian sekolah dan ujian nasional. Ketiga Zoom, merupakan aplikasi video conference yang bisa digunakan dalam BJJ BDR daring secara tatap muka langsung oleh guru dan siswa atau siapapun yang menggunakannya melalui layar computer, laptop, dan smartphone. Zoom merupakan platform tatap muka yang mana guru dan siswa/dosen dan mahasiswa bisa langsung berinteraksi selayaknya bertemu langsung. Aplikasi Zoom sangat sesuai untuk kegiatan pembelajaran online, yang mampu mendukung jumlah peserta belajar lebih dari 20 orang, dan fitur conference tool bisa digunakan oleh setiap peserta. Zoom memungkinkan untuk menulis dan berbicara secara bersamaan. Penggunaan aplikasi ini tidak harus diunduh, cukup dengan mengklik link yang diberikan dan dibuka dengan aplikasi Zoom, bila menggunakan smartphone didownload terlebih dahulu melalui aplikasi Play Store.

\section{Metode Pembelajaran}

Guru dalam memilih dan memakai metode merupakan sesuatu yang penting dalam menyampaikan materi pelajaran kepada siswa untuk tercapainya tujuan pembelajaran. Metode adalah cara kerja yang teratur dan bersistem untuk dapat melaksanakan suatu kegiatan guna mencapai tujuan yang ditentukan (Kementerian Pendidikan dan Kebudayaan RI, n.d.). Metode Pendidikan Islam adalah jalan untuk menanamkan agama pada diri seseorang sehingga terlihat dalam pribadi objek sasaran yaitu pribadi Islam (Lilis Lismayanti et al., 2020). Dalam proses pendidikan Islam, metode mempunyai kedudukan penting dalam upaya mencapai tujuan, karena itu menjadi sarana dalam menyampaikan materi pelajaran yang tersusun dalam kurikulum (Qowim, 2020). 
3892 Perencanaan Strategi Guru dalam Pembelajaran Pendidikan Agama Islam pada masa Covid-19- Wahid Hasim, Kusen, Hartini, Mirzon Daheri

DOI: https://doi.org/10.31004/edukatif.v3i6.1147

Tanpa metode, suatu materi pelajaran tidak akan dapat berproses secara efisien dan efektif dalam kegiatan belajar mengajar menuju tujuan pendidikan.

Guru menyampaikan materi pelajaran dalam bentuk power point dan menerangkannya dalam bentuk rekaman pesan suara dikirim kepada siswa melalui WhatsApp group sesuai dengan kelasnya masing-masing. (kutipan wawancara X3). Dalam belajar mengajar, selain menggunakan power point dan voice note guru mengadakan tanya jawab baik secara tertulis melalui WhatsApp maupun lisan dengan voice note dan Zoom (kutipan wawancara X4). Setiap selesai pertemuan belajar mengajar, guru memberikan tugas kepada siswa baik secara tertulis maupun lisan. Tugas tertulis yaitu latihan mengerjakan soal-soal, tugas lisan yakni hafalan ayat-ayat al-Qur'an dan Hadits dan menagihnya pada pertemuan berikutnya (kutipan wawancara X5).

Dari temuan penelitian didapatkan bahwa metode yang digunakan guru yaitu pertama metode ceramah. Metode ceramah adalah sebuah metode mengajar dengan menyampaikan informasi secala lisan kepada peserta didik, dengan langkah-langkah persiapan, penyajian, generalisasi, dan aplikasi penggunaan. Ceramah yang digunakan guru dalam hal ini yakni menerangkan materi pelajaran yang telah dipersiapkan dalam bentuk power point dan menerangkannya dalam bentuk rekaman pesan suara (voice note) yang diberikan kepada siswa melalui WhatsApp sesuai kelasnya. Kedua metode tanya jawab adalah cara yang digunakan guru kepada peserta didik dengan memberikan pertanyaan-pertanyaan yang telah direncanakan oleh pendidik agar peserta didik dapat dengan mudah pertanyaan-pertanyaan yang diberikan, dengan langkah-langkah yang harus ditempuh dalam menyusun dan menyajikan pertanyaan untuk tercapainya tujuan utama pendidikan Islam, yaitu terbentuknya pribadi yang beriman yang senantiasa siap mengabdi kepada Allah SWT. Dalam hal ini tanya jawab diadakan baik secara tertulis melalui WhatsApp maupun lisan melalui pesan suara (voice note) dan Zoom. Ketiga metode pemberian tugas adalah cara mengajar guru dengan memberikan tugas-tugas tertentu kepada siswa, sedangkan hasil tersebut diperiksa oleh guru dan siswa mempertanggung jawabkannya dengan cara menjawab tes yang diberikan guru, dengan menyampaikannya kemuka berupa lisan, dan dengan cara tertulis. Penggunaan metode ini, dimana guru memberikan tugas tertulis berupa soal-soal latihan, baik pilihan ganda maupun essay yang dikirim melalui google forms. Kemudian tugas yang diberikan secara lisan berupa hafalan ayat-ayat al-Qur'an dan Hadits dimana siswa disuruh merekam hafalannya dalam bentuk video atau rekaman suara (voice note) kemudian dikirimkan ke guru melalui Whats App.

\section{Sumber Belajar dan Bahan Ajar}

Sumber belajar merupakan sesuatu yang penting dalam proses pembelajaran untuk tercapainya tujuan pendidikan. Sumber belajar adalah bahan-bahan yang dimanfaatkan dan diperlukan dalam proses pembelajaran yang apat berupa buku teks, media cetak, media elektronik, narasumber, lingkungan sekitar dan sebagainya yang dapat meningkatkan kadar keaktifan dalam proses pembelajaran (Manurung, 2020). Sedangkan bahan ajar adalah isi materi pelajaran yang diberikan kepada siswa pada saat berlangsungnya proses belajar mengajar (Yusuf \& Darimi, 2020) dan, melalui bahan ajar ini siswa diantarkan kepada tujuan pengajaran. Dengan kata lain, tujuan yang akan dicapai siswa diwarnai dan dibentuk oleh bahan ajar.

Di SMPIT An-Nida' sumber belajar dan bahan ajar yang digunakan diambil dari buku paket Pendidikan Agama Islam sesuai dengan kelasnya, Al-Qur'an dan terjemahannya, kitab Hadits, internet, buku penunjang, media cetak seperti majalah dan surat kabar, dan media elektronik seperti televisi untuk mengetahui perkembangan terkini tentang sesuatu, misalnya tentang COVID-19 (kutipan wawancara X3, X4, dan X5).

Dari hasil penelitian didapatkan bahwa sumber belajar dan bahan ajar yang digunakan guru yaitu pertama buku paket atau buku teks. Permendiknas Nomor 2 Tahun 2008 menjelaskan bahwa buku teks adalah buku acuan wajib untuk digunakan disatuan pendidikan dasar dan menengah atau perguruan tinggi yang memuat materi pembelajaran dalam rangka peningkatan keimanan, ketakwaan, akhlak mulia, dan kepribadian, penguasaan ilmu pengetahuan dan teknologi, peningkatan kepekaan dan kemampuan estetis, peningkatan kemampuan kinestetis kesehatan yang disusun berdasarkan standar nasional pendidikan. Buku teks adalah 
3893 Perencanaan Strategi Guru dalam Pembelajaran Pendidikan Agama Islam pada masa Covid-19- Wahid Hasim, Kusen, Hartini, Mirzon Daheri

DOI: https://doi.org/10.31004/edukatif.v3i6.1147

buku yang berisi uraian bahan tentang mata pelajaran atau bidang studi tertentu, yang dsusun secara sistematis dan telah diseleksi berdasarkan tujuan tertentu, orientasi pengajaran, dan perkembangan siswa, untuk diasimilasikan (Wilsa, 2019). Buku teks yang dipakai guru dan siswa dalam hal ini yaitu buku teks Pendidikan Agama Islam untuk SMP kelas 7, 8 , dan kelas 9 sesuai dengan Kurikulum Nasional dan Kurikulum Jaringan Sekolah Islam Terpadu (JSIT) Indonesia. Penulis Dr. Abas Mansur Tamam, MA, Penerbit Yayasan Pendidikan dan Pemberdayaan Umat (YPPU) Depok- Jawa Barat Cetakan ke 4, Mei 2018, Cetakan ke 5 Juni 2019, dan Cetakan ke 6, April 2020. Sumber belajar dan bahan ajar yang digunakan selanjutnya yakni AlQur'an dan Terjemahannya, kitab-kitab Hadits yang berhubungan dengan materi pembelajaran, buku penunjang, internet (Google), media cetak, dan media elektronik. Media cetak dan media elektronik digunakan untuk mengetahui perkembangan terkini tentang sesuatu yang kemudian dihubungkan dengan materi pembelajaran, misalnya tentang perkembangan COVID-19.

\section{Alokasi Waktu dalam Pembelajaran}

Pelaksanaan kegiatan belajar mengajar yang baik tentunya harus memperhatikan waktu yang akan dimanfaatkan pada saat kegiatan pembelajaran dilaksanakan. Lamanya waktu pembelajaran dari awal sampai akhir harus disesuaikan dengan kebutuhan siswa. Alokasi waktu adalah jumlah waktu yang dibutuhkan untuk tercapainya suatu kompetensi dasar tertentu, dengan memperhatikan minggu efektif per semester, alokasi waktu mata pelajaran per minggu, dan jumlah kompetensi per semester (A. N. Hidayat \& Purwadi, 2019). Dengan adanya julah waktu ini kegiatan pembelajaran siswa dikelas akan lebih terarah. Menurut Mulyasa (2003) alokasi waktu adalah jumlah waktu yang diperlukan pada setiap kompetensi dasar dilakukan dengan mempertimbangkan jumlah minggu efektif dan alokasi mata pelajaran perminggu dengan mempertimbangkan jumlah kompetensi dasar, keluasan, kedalaman, tingkat kesulitan, dan tingkat kepentingannya.

Lamanya waktu belajar mengajar untuk setiap hari 4 jam 30 menit, pembelajaran daring dimulai pukul 07.00 WIB dan selesai pukul 11.30 WIB. Durasi waktu ini termasuk untuk istirahat siswa dan guru. Untuk setiap guru diberikan waktu 60 menit, pembagian waktu ini disesuaikan dengan jumlah mata pelajaran dalam setiap harinya. Untuk teknis penggunaan waktunya diserahkan pada guru mata pelajaran masing-masing sesuai dengan jadwalnya (kutipan wawancara X1). Kegiatan pembelajaran daring dimasa pandemi COVID-19 ini diberikan waktu 60 menit untuk setiap kali pertemuan dalam setiap minggu, 20 menit digunakan guru untuk persiapan mengajar dan istirahat, 40 menit untuk pelaksanaan pembelajaran yang dibagi 5 menit untuk kegiatan pembuka, 30 menit untuk kegiatan inti menyampaikan materi pelajaran; dan 5 menit untuk kegiatan penutup. Kemudian untuk tugas, absen, mengecek keaktifan siswa dalam belajar dan lain-lain waktunya sampai pukul $21.00 \mathrm{WIB}$ atau jam sembilan malam (kutipan wawancara X3, X4, dan X5).

Dari hasil penelitian didapatkan bahwa jumlah waktu yang disediakan dalam pembelajaran daring untuk setiap harinya 4 jam 30 menit, kegiatan ini dimulai pukul 07.00 WIB sampai dengan pukul 11.30 WIB. Untuk setiap guru mata pelajaran diberikan waktu 60 menit dalam mengajar untuk satu minggu. Waktu 60 menit ini digunakan guru 20 menit untuk persiapan mengajar dan istirahat, 40 menit untuk kegiatan pembelajaran yang terdiri 5 menit untuk kegiatan pembukaan seperti mengucapkan salam, menanya kabar siswa, menagih tugas, tagihan shalat duha, mengisi absen dan ain-lain. 30 menit digunakan untuk kegiatan inti pembelajaran yakni menyampaikan materi pelajaran kepada siswa yang telah dipersiapkan, dan 5 menit digunakan untuk kegiatan penutup pembelajaran seperti melakukan evaluasi tes terhadap siswa sebagai follow aff materi pelajaran yang telah disampaikan, memberikan tugas, memotifasi dan menginagtkan siswa untuk selalui mematuhi protokol kesehatan COVID-19, dan mengucapkan salam untuk mengakhiri pembelajaran.

Lamanya waktu pembelajaran daring dimasa pandemi COVID-19 ini tidak ada ketentuan baku yang ditetapkan pemerintah. Hal ini sebagaimana dijelaskan Mendikbud Nadiem Anwar Makarim bahwa guru diminta untuk memperhatikan waktu belajar siswa ditengah masa Pembelajaran Jarak Jauh, guru harus bisa memilih waktu belajar daring dengan belajar independen. Guru harus menemukan formula mengajar yang 
sesuai dengan kemampuan anak, karena itu, belajar daring atau pembelajaran jarak jauh tidak sepenuhnya harus dilakukan didepan perangkat keras selama berjam-jam (cnnindonesia.com). Satriwan Salim (Wakil Sekretaris Federasi Guru Indonesia) mengatakan bahwa dengan tidak adanya kurikulum adaptif selama pendemi ini, para guru pun tidak memiliki pedoman nasional untuk mengatur durasi belajar daring maupun luring. Sekolah dan guru hanya fokus pada surat edaran Mendikbud nomor 4 tahun 2019 tentang pelaksanaan kebijakan pendidikan dalam masa darurat penyebaran COVID-19 yang diperkuat dengan surat edaran Setjen Kemendikbud nomor 15 tahun 2019. Dalam panduan tersebut tidak ada aturan tentang durasi belajar. Dari hasil pantauan dilapangan didapatkan, pada waktu normal durasi belajar siswa untuk tingkat SMP dan SMA/SMK berlangsung selama 8 jam, masuk sekolah pukul 7.00 WIB dan keluar pukul 15.00 WIB. Namun pada situasi pandemi, khusus untuk daring, siswa mulai belajar pukul 7.00 WIB dan selesai pukul 11.30 WIB atau mulai pukul 8.00 WIB dan selesai pukul 12.00 WIB. Sedangkan untuk PAUD dan SD, durasi PJJ umumnya berlangsung selama dua atau tiga jam. Oleh karenanya Kemendikbud diminta untuk menggunakan rekomendasi durasi pembelajaran jarak jauh sesuai rekomendasi dari Ikatan Dokter Anak Indonesia (IDAI), pasalnya selain mempertimbangkan ketersediaan kouta internet, Kemendikbud juga harus fokus pada kesehatan peserta didik. Ketua Umum Pusat IDAI Aman B Pulungan mengeluarkan rekomendasi durasi selama PJJ-BDR Daring, ia mengatakan bahwa untuk siswa SD sebaiknya tidak boleh lebih dari 90 menit dalam sehari, dan untuk siswa menengah tidak boleh lebih dari dua jam per hari, kemudian orang tua agar selalu mendampingi anak untuk melakukan belajar melalui layar laptop, computer, maupun gawai (beritasatu.com).

\section{Penilaian Hasil Belajar Formatif}

Penilaian hasil belajar secara formatif tentunya dilakukan setiap guru dalam setiap pembelajaran terhadap siswa untuk mengetahui sejauhmana ketercapainnya setelah mengikuti setiap kompetensi dasar yang menjadi tujuan program pembelajaran. Evaluasi formatif secara prinsip merupakan evaluasi yang dilaksanakan ketika program masih berlangsung (Iswahyudi, 2020). Tujuannya untuk mengetahui seberapa jauh program yang dirancang dapat berlangsung, sekaligus dapat mengidentifikasi hambatan. Dengan diketahuinya hambatan dan hal-hal yang menyebabkan program tiak lancar, pengambil keputusan secara dini dapat mengadakan perbaikan yang mendukung kelancaran pencapaian tujuan program. Evaluasi formatif adalah evaluasi pembelajaran yang dilaksanakan setiap siswa selesai mempelajari KD yang harus dicapai pada mapel tertentu disatu pokok bahasan mapel tersebut untuk menilai ketercapaian KD, jika siswa belum mencapainya maka siswa diadakan remedial (Anam, 2021). Fungsinya untuk memperbaiki proses belajar mengajar kearah yang lebih baik atau memperbaiki program satuan pelajaran. Tujuannya untuk mengetahui sampai dimana penguasaan siswa terhadap bahan yang telah diajarkan dalam suatu program satuan pelajaran. Aspek yang dinilai berkenaan dengan hasil kemampuan belajar siswa meliputi pengetahuan, keterampilan, sikap, dan penguasaan terhadap materi pelajaran yang telah diberikan. Waktunya dilaksanakan setiap akhir pelaksanaan suatu program belajar mengajar (setiap akhir pelajaran).

Penilaian formatif sebagai follow up kepada siswa, dilakukan setelah kegiatan pembelajaran dilaksanakan, pelaksanaannya setiap bab yang menjadi kompetensi dasar selesai dipelajari, bentuknya ulangan harian dengan memberikan tugas. Keaktifan siswa dalam pembelajaran (kehadiran, bertanya dan menjawab pertanyaan) kami masukan kedalam penilaian karakter (kutipan wawancara X3, X4, dan X5). Demikian sistem penilaian yang ditempuh guru di SMPIT An-Nida' Lubuk Linggau.

Dari hasil wawancara didapatkan bahwa para guru dalam melaksanakan penilaian hasil belajar secara formatif sebagai follow up terhadap siswa dilakukan dalam bentuk pemberian tugas, baik tugas lisan (hafalan ayat-ayat Qur'an dan Hadits) maupun tertulis (pilihan ganda dan essay) yang oleh guru disebut tagihan tugas. Hal ini dilakukan setelah siswa selesai mempelajari setiap bab yang menjadi Kompetensi Dasar, tujuannya untuk mengetahui ketercapaian KD materi pelajaran yang telah diberikan. Selanjutnya keaktipan siswa dalam 
3895 Perencanaan Strategi Guru dalam Pembelajaran Pendidikan Agama Islam pada masa Covid-19- Wahid Hasim, Kusen, Hartini, Mirzon Daheri

DOI: https://doi.org/10.31004/edukatif.v3i6.1147

pembelajaran seperti keaktipan kehadiran, bertanya dan menjawab pertanyaan dimasukan kedalam penilaian karakter.

\section{SIMPULAN DAN SARAN}

Dari hasil penelitian didapatkan bahwa perencanaan strategi guru dalam Pembelajaran Jarak Jauh Belajar Dari Rumah Dalam Jaringan (PJJ BDR Daring) akibat COVID-19, diawali dari kesiapan siswa, menyiapkan Rencana Pelaksanaan Pembelajaran Daring (RPPD), penggunaan strategi dalam pembelajaran, penggunaan media pembelajaran, metode pembelajaran, sumber belajar dan bahan ajar, alokasi waktu, dan penilaian hasil belajar formatif.

Hendaknya Kemendikbud-Ristek memberikan petunjuk teknis tentang pembuatan RPPD dan alokasi waktu yang jelas sehubungan dengan adanya perubahan sistem Pembelajaran Tatap Muka (PTM) ke sistem Pembelajaran Jarak Jauh- Belajar Dari Rumah (PJJ- BDR) Daring, sehingga guru tidak mengalami kesulitan dalam membuat RPPD dan penggunaan waktu secara Daring. Kemudian guru terus berupaya meningkatkan kompetensi pembelajaran berbasis Teknologi Informasi dan Komunikasi (TIK) dengan cara mengikuti pelatihan guna meningkatkan kemampuan strategi guru dalam pembelajaran.

\section{DAFTAR PUSTAKA}

Ahmadi, A., \& Prasetya, J. T. (2005). Strategi Belajar Mengajar. Pustaka Setia.

Akbar, E. (2019). Penggunaan Media Pembelajaran Berbasis Multimedia Interaktif (Mmi) Untuk Meningkatkan Hasil Belajar Peserta Didik Pada Mata. Journal.Institutpendidikan.Ac.Id. Https://Journal.Institutpendidikan.Ac.Id/Index.Php/Tekp/Article/View/463

Anam, N. (2021). Manajemen Kurikulum Pembelajaran Pai. Ta'limdiniyah: Jurnal Pendidikan Agama Islam (Journal Of Islamic Education Studies), 1(2), 129-143. Https://Doi.Org/10.53515/Tdjpai.V1i2.10

Arikunto, S. (2010). Prosedur Penelitian Suatu Pendekatan Praktik. Rineka Cipta.

Aripin, S., Silalahi, N., ... K. U.-P. By H. E., \& 2020, Undefined. (2020). Pengenalan Dan Penggunaan Website Ujian Online Sebagai Media Pembelajaran Pada Siswa/Siswi Sma Negeri $1 \mathrm{Stm}$ Hilir. Ejurnal.Seminar-Id.Com, 1(2). Https://Ejurnal.Seminar-Id.Com/Index.Php/Jrespro/Article/View/552

Ayp, C. I. (2021, Juli 8). Korban Meninggal Covid-19 Dunia 4 Juta, Indonesia Posisi 17. Cnnindonesia. Https://Www.Cnnindonesia.Com/Internasional/20210708113855-106-664910/Korban-MeninggalCovid-19-Dunia-4-Juta-Indonesia-Posisi-17

Cahyono, H. T. (2019). Strategi Guru Aqidah Akhlak Dalam Membentuk Karakter Mandiri Siswa Di Mts AlHuda Bandung Tulungagung. Iain Tulung Agung.

Daheri, M., Juliana, J., Deriwanto, D., \& Amda, A. D. (2020). Efektifitas Whatsapp Sebagai Media Belajar Daring. Jurnal Basicedu, 4(4), 775-783. Https://Doi.Org/10.31004/Basicedu.V4i4.445

Pedoman Pembatasan Sosial Berskala Besar Dalam Rangka Percepatan Penanganan Corona Virus Disease (Covid-19), (2020).

Fahmi, M., Mukti, A., \& Nahar, S. (2019). Efektifitas Pembelajaran Agama Sekolah Dasar Islam Terpadu Di Kota Langsa. In Observasi (Vol. 02, Nomor 2). Http://Jurnal.StitRh.Ac.Id/Index.Php/Obs/Article/View/100

Fathurrohman, F. (2020). Implementasi Pembelajaran Pendidikan Agama Islam Berbasis Masalah Dalam Meningkatkan Kemampuan Metakognitif Siswa. Modeling: Jurnal Program Studi Pgmi, 7(2), 270-288. Https://Doi.Org/10.36835/Modeling.V6i2.719

Hasnidar, H., Guru, E. E.-M. J. P., \& 2020, Undefined. (N.D.). Pengaruh Pembelajaran Contextual Teaching 
3896 Perencanaan Strategi Guru dalam Pembelajaran Pendidikan Agama Islam pada masa Covid-19- Wahid Hasim, Kusen, Hartini, Mirzon Daheri

DOI: https://doi.org/10.31004/edukatif.v3i6.1147

Learning Terhadap Hasil Belajar Pkn Murid Sekolah Dasar. Ummaspul.E-Journal.Id. Diambil 19 Agustus 2021, Dari Https://Ummaspul.E-Journal.Id/Mgr/Article/Download/327/155

Heriyanto, H. (2019). Implementasi Thematic Analysis Dalam Penelitian Ilmu Perpustakaan Dan Informasi. Anuva: Jurnal Kajian Budaya, Perpustakaan, Dan Informasi, 3(1), 27-31.

Hidayat, A. N., \& Purwadi, D. (2019). Penerapan Lembar Kegiatan Siswa (Lks) Pada Kompetensi Dasar Menerapkan Teknik Dasar Perhitungan Azimuth. Jurnal Kajian Pendidikan Teknik Bangunan, 5(1). Https://Ejournal.Unesa.Ac.Id/Index.Php/Jurnal-Kajian-Ptb/Article/View/29833

Hidayat, A., Sa'diyah, M., \& Lisnawati, S. (2020). Metode Pembelajaran Aktif Dan Kreatif Pada Madrasah Diniyah Takmiliyah Di Kota Bogor. Edukasi Islami: Jurnal Pendidikan Islam, 9(01), 71-86. Https://Doi.Org/10.30868/Ei.V9i01.639

Iswahyudi, J. (2020). Evaluasi Program Boarding School Dalam Upaya Meningkatkan Mutu Lulusan Di Man 1 Gunungkidul. Jurnal Pendidikan Madrasah, 5(2), 165-172. Https://Doi.Org/10.14421/Jpm.2020.52-01

Kementerian Pendidikan Dan Kebudayaan Ri. (N.D.). Kbbi Daring. Kbbi.Kemdikbud.Go.Id. Diambil 19 Agustus 2021, Dari Https://Kbbi.Kemdikbud.Go.Id/Entri/Strategi

Khamim, N. (2019). Penerapan Pendidikan Agama Islam Pada Keluarga Millenial | Attaqwa: Jurnal Ilmu Pendidikan Islam. At-Taqwa: Jurnal Ilmu Pendidikan Islam, 15(2), 132-142. Http://Www.Jurnal.Staidagresik.Ac.Id/Index.Php/Attaqwa/Article/View/18

Lilis Lismayanti, Badrudin, U., \& Mukhsin, A. (2020). Edukasi Perilaku Hidup Bersih Dan Sehat Dalam Perspektif Al- Islam Dengan Pendekatan Fit For School. Jurnal Seminar Nasional, 2(01), 78-83. Http://Www.Ejurnal.Stikesrespati-Tsm.Ac.Id/Index.Php/Semnas/Article/View/249

Ma'shumah, F., \& Muhsin, M. (2019). Pengaruh Motivasi Belajar, Disiplin Belajar, Cara Belajar Dan Interaksi Teman Sebaya Terhadap Kesiapan Belajar. Economic Education Analysis Journal, 8(1), 318 332. Https://Doi.Org/10.15294/Eeaj.V8i1.29779

Majid, A. (2014). Pembelajaran Tematik Terpadu. Remaja Rosdakarya.

Manurung, P. (2020). Pemanfaatan Sumber Belajar Dalam Bidang Bimbingan Dan Konseling. Hikmah, 17(2), 115-127. Https://Doi.Org/10.53802/Hikmah.V17i2.96

Megawati, R., Leksono, I. P., \& Harwanto, H. (2021). Implementasi Pembelajaran Kooperatif Tipe Jigsaw Terhadap Hasil Belajar Matematika Ditinjau Dari Tipe Kepribadian Siswa. Jurnal Education And Development, 9(1), 19-19. Https://Doi.Org/10.37081/Ed.V9i1.2228

Instruksi Menteri Dalam Negeri Nomor 22 Tahun 2021 - Regulasi | Covid19.Go.Id, Pub. L. No. 22, Covid19.Go.Id (2021). Https://Covid19.Go.Id/P/Regulasi/Instruksi-Menteri-Dalam-Negeri-Nomor-22Tahun-2021

Surat Edaran Nomor 4 Tahun 2020 Tentang Pelaksanaan Kebijakan Pendidikan Dalam Masa Darurat Penyebaran Corona Virus Disease (Covid-19), Pub. L. No. 4 Tahun 2020, Kemendikbud.Go.Id (2020). Https://Www.Kemdikbud.Go.Id/Main/Blog/2020/03/Se-Mendikbud-Pelaksanaan-Kebijakan-

Pendidikan-Dalam-Masa-Darurat-Penyebaran-Covid19

Novitasarii, N. (2021). Penerapan Protokol Kesehatan Dalam Pembelajaran Tatap Muka Pada Masa Era New Normal Di Paud Plus Darussalam. Al-Hikmah: Indonesian Journal Of Early Chilhood Islamic Education, $\quad 5(1), \quad 39-50$. Http://Journal.Iaialhikmahtuban.Ac.Id/Index.Php/Ijecie/Article/Download/191/127

Nursyifah, E. (2019). Penggunaan Model Pembelajaran Inkuiri Dalam Membangun Kemampuan Berpikir Kritis Siswa Sekolah Dasar. Prosiding Seminar Nasional Pendidikan , 1, 810-817. Https://Prosiding.Unma.Ac.Id/Index.Php/Semnasfkip/Article/View/116

Parlindungan, Putro, D., M Al Ghani, \& Nurhalizah, S. (2020). Peranan Guru Dan Orang Tua Dalam Menghadapi Pembelajaran Jarak Jauh (Pjj) Dimasa Pandemi Covid-19 Di Sds Islam An-Nuriyah. Prosiding Seminar Nasional Penelitian Lppm Umj, 
3897 Perencanaan Strategi Guru dalam Pembelajaran Pendidikan Agama Islam pada masa Covid-19- Wahid Hasim, Kusen, Hartini, Mirzon Daheri

DOI: https://doi.org/10.31004/edukatif.v3i6.1147

Https://Jurnal.Umj.Ac.Id/Index.Php/Semnaslit/Article/View/8795

Prodjo, W. A. (2020, Juni 12). Pembelajaran Jarak Jauh Bukan Pembelajaran Daring, Ini Penjelasannya. Kompas.Com. Https://Www.Kompas.Com/Edu/Read/2020/06/16/200131471/Pembelajaran-Jarak-JauhBukan-Pembelajaran-Daring-Ini-Penjelasannya

Qowim, A. N. (2020). Metode Pendidikan Islam Perspektif Al-Qur'an. Iq (Ilmu Al-Qur'an): Jurnal Pendidikan Islam, 3(01), 35-58. Https://Doi.Org/10.37542/Iq.V3i01.53

Rafsanjani, T. A., \& Razaq, M. A. (2019). Internalisasi Nilai-Nilai Keislaman Terhadap Perkembangan Anak Di Sekolah Dasar Muhammadiyah Kriyan Jepara. Profetika: Jurnal Studi Islam, 16-29. Https://Doi.Org/10.23917/Profetika.V20i1.8945

Rahman, F., \& Hidayat, R. (2019). Tindak Ujaran Pada Anak Hiperaktif Usia Dua Tahun. Deiksis, 11(01), 51-58. Https://Doi.Org/10.30998/Deiksis.V11i01.3020

Reski, D., \& A Ilyas -. (2019). Konsep Kesiapan Siswa Dalam Mengerjakan Tugas. Schoulid: Indonesian Journal Of School, 1(2), 33-38. Https://Doi.Org/10.23916/08419011

Sa'dullah, M. (2020). Pandemi Covid-19 Dan Implikasinya Terhadap Pembelajaran Pendidikan Agama Islam Di Smpn 1 Banyubiru Kabupaten Semarang. Institut Agama Islam Negeri (Iain) Salatiga.

Samsudin, S. (2021). Strategi Pembelajaran Ekspositori Guru Pendidikan Agama Islam Untuk Menanamkan Nilai-Nilai Multikultural. Jurnal Educatio Fkip Unma, 7(1), 29-35. Https://Doi.Org/10.31949/Educatio.V7i1.759

Sanjaya, W. (2008). Perencanaan \& Desain Sistem Pembelajaran. Prenanda Media.

Sudirman, S. (2020). Upaya Peningkatan Kompetensi Guru Dalam Menyusun Silabus Dan Rpp Melalui Supervisi Akademik Yang Berkelanjutan Di Sman 1. Journal.Lldikti9.Id, 2(2), 81-90. Https://Doi.Org/10.37541/Upaya

Sugiana, A. (2019). Pengembangan Kurikulum Pendidikan Agama Islam Dan Implementasinya Di Mts Nurul Ummah Yogyakarta. Jurnal Pendidikan Agama Islam, 16(1), 17-34. Https://Doi.Org/10.14421/Jpai.Jpai.2019.161-02

Sulfemi, W. B. (2019). Kompetensi Profesionalisme Guru Indonesia Dalam Menghadapi Mea. Prosiding Seminar Nasional Stkip Muhammadiyah Bogor, 62-77. Https://Doi.Org/10.31227/Osf.Io/Czxus

Tanzimah, T. (2020). Keterkaitan Model Pembelajaran Think Pair Share (Tps) Dengan Pendekatan Contextual Teaching And Learning (Ctl) Dalam Pembelajaran Matematika. Jurnal Dosen Universitas Pgri $\begin{array}{llll}\text { Palembang, } & O(0), & 762-772 . & \text { Https://Jurnal.Univpgri- }\end{array}$ Palembang.Ac.Id/Index.Php/Prosiding/Article/View/4035

Vidiarti, E., Zulhaini, Z., \& Andrizal, A. (2019). Analisis Kemampuan Guru Pendidikan Agama Islam Dalam Penyusunan Rencana Pelaksanaan Pembelajaran (Rpp) Kurikulum 2013. J-Pai: Jurnal Pendidikan Agama Islam, 5(2), 102-112. Https://Doi.Org/10.18860/Jpai.V5i2.5858

Warianie, L. (2020). Peranan Penting Guru, Orang Tua Dan Siswa Dalam Menghadapi Pembelajaran Jarak Jauh Di Masa Pandemi Covid 19. Enggang: Jurnal Pendidikan, Bahasa, Sastra, Seni, Dan Budaya, 1(1), 16-29. Https://E-Journal.Upr.Ac.Id/Index.Php/Enggang/Article/View/2350

Wilsa, A. W. (2019). Perbedaan Hasil Belajar Siswa Yang Menggunakan Multimedia Interaktif Dengan Buku Teks Dalam Pembelajaran Biologi Di Sma. Mangifera Edu, 4(1), $62-70$ Https://Doi.Org/10.31943/Mangiferaedu.V4i1.42

Yusuf, M., \& Darimi, I. (2020). Pengayaan Materi Pendidikan Agama Islam Di Sekolah Menengah Atas Di Aceh Jaya. Jurnal Mudarrisuna: Media Kajian Pendidikan Agama Islam, 10(1), 75-90. Https://Doi.Org/10.22373/Jm.V10i1.6791

Zulfikar. (2020). Refungsionalisasipendidikan Keluarga Pada Masa Pandemi (Studi Pada Wali Murid Smpi Al Hasanah Kota Bengkulu). Institut Agama Islam Negeri (Iain) Bengkulu. 